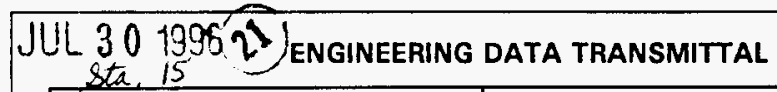

Pago 1 of 1

1. EDT 602624

\begin{tabular}{|l|l|}
\hline 2. To: (Receiving Organization) & 3. From: corig \\
TWRS SAR Engineering & TWRS SAR En \\
\hline 5. Proj./Prog./Dept./Div.: & $\begin{array}{l}\text { 6. cog. Engr.: } \\
8 M 100\end{array}$ \\
G. W. Ryan
\end{tabular}

8. Originator Remarks:

This document was developed and approved by Westinghouse Savannah River Site (WSRS) personnel and is being submitted for approval and release into the Hanford document control system.

\section{Receiver Remarks:}

$N / A$
3. From: (Originating Organization)

G. H. Ryan
4. Related EOT NO.:

N/A

7. Purchase Order No.:

N/A

9. Equip./Component No.:

$N / A$

10. Systenv/Btdg./facility:

TWRS

12. Mejor Assm. Dwg. No.:

N/A

13. Permit/Permit Applicetion No.: $N / A$

14. Required Response Date: $7 / 29 / 96$

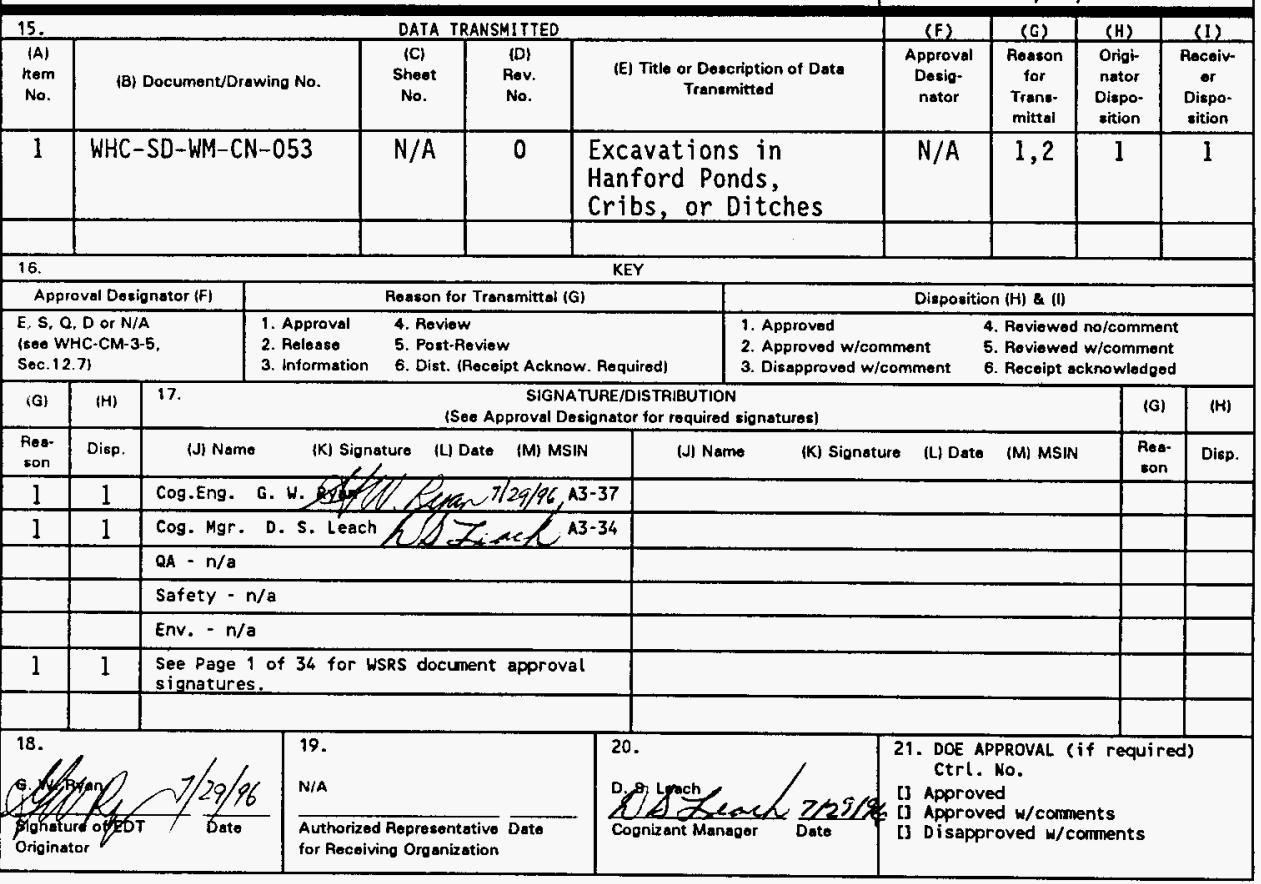




\title{
Excavations in Hanford Ponds, Cribs, or Ditches
}

\author{
G. W. Ryan
}

West inghouse Hanford Company, Richland, WA 99352

U.S. Department of Energy Contract DE-ACO6-87RL10930

$\begin{array}{lll}\text { EDT/ECN: } & 602624 & \text { UC: } 510 \\ \text { Org Code: } & 8 \text { M100 } & \text { Charge Code: N1FC3 } \\ \text { B\&R Code: } & \text { EW3120071 } & \text { Total Pages: } 35\end{array}$

Key Words: pond, crib, ditch, excavation, TWRS, tank farms

Abstract: This document supports the development and presentation of the following accident scenario in the TWRS Final Safety Analysis Report:

\section{Unplanned Excavation/Drilling in Pond/Ditch/Crib.}

The calculations needed to quantify the risk associated with this accident scenario are included within.

TRADEMARK DISCLAIMER. Reference herein to any specific commercial product, process, or service by trade name, trademark, manufacturer, or otherwise, does not necessarily constitute or imply its endorsement, recomendation, or favoring by the United States Government or any agency thereof or its contractors or subcontractors.

Printed in the United States of America. To obtain copies of this document, contact: WHC/BCS Document Control Services, P.0. Box 1970, Mailstop H6-08, Richtand HA 99352, Phone (509) 372-2420;
Fax (509) 376-4989.
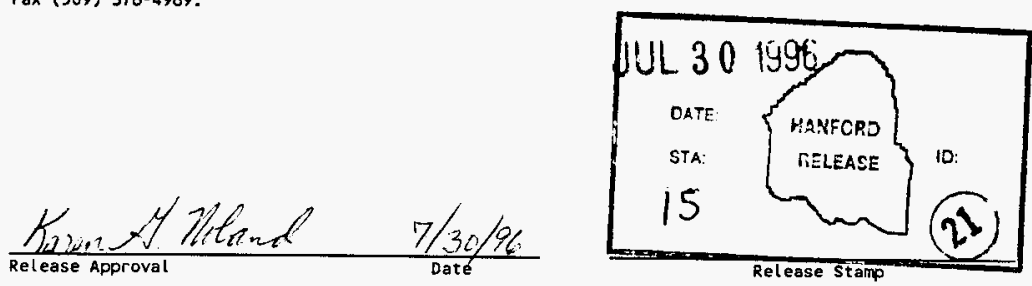

\section{Approved for Public Release}




\section{Calculation Cover Sheet}

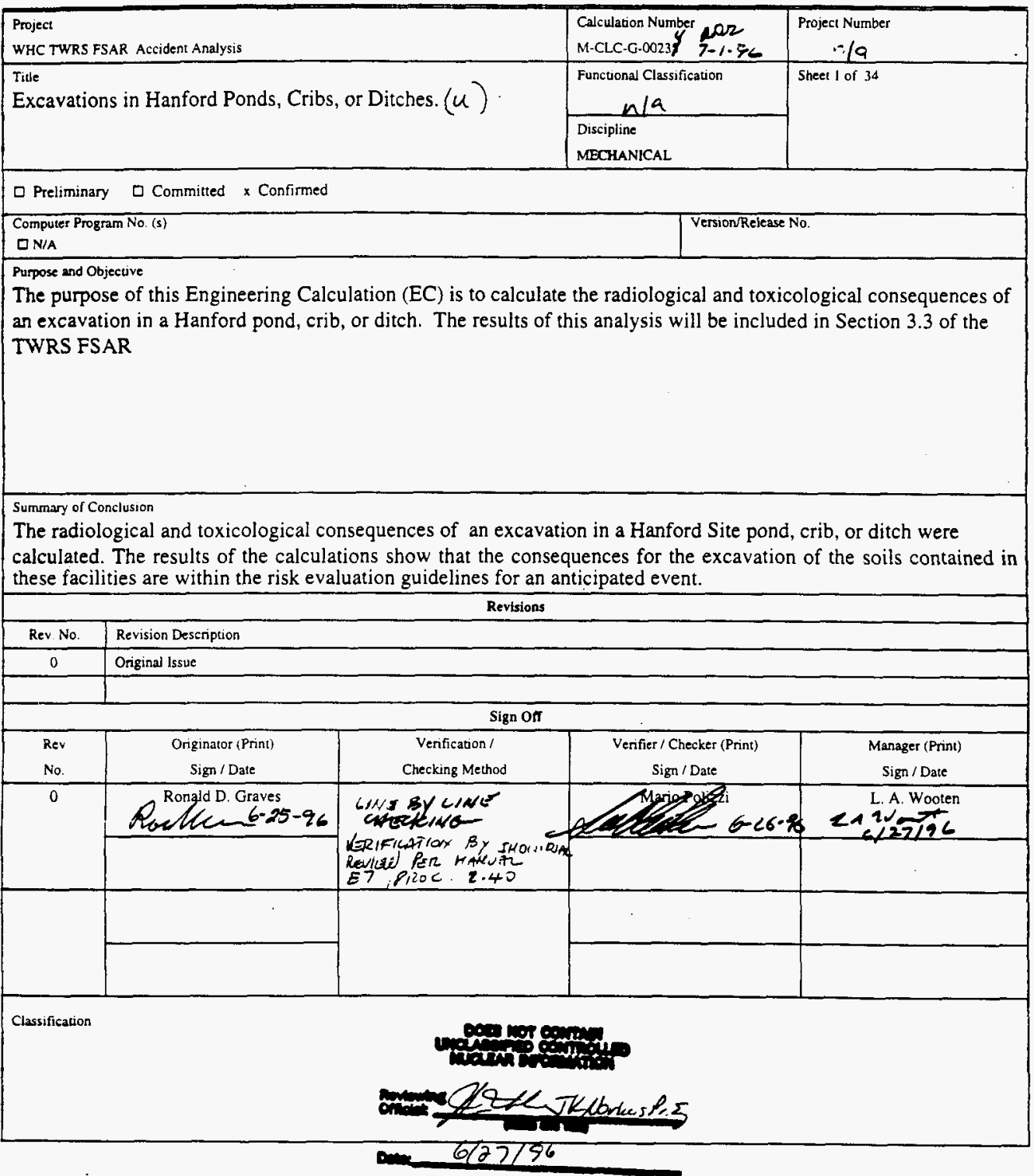


Calculation No. M-CLC-G.00234

Sheet No. 2 of 34

Rev. 0

\section{TABLE OF CONTENTS}

Introduction:

References:

Input:

Assumptions:

Analytical Methods and Calculations:

Airborne Source Term

Dose Consequence Analysis

Results:

Conclusion:

Appendices:

NAME

\begin{tabular}{ll}
\multicolumn{2}{l}{ CONFIGURATION } \\
Control & Version \\
Yes & No \\
Yes & No \\
Yes & No \\
Yes & No
\end{tabular}


Calculation No. M-CLC-G-00234

Sheet No. 3 of 34

Rev. 0

\section{CALC-NOTE CHECKLIST}

REVIEWER(S):

NAME (PRDNT OR TYPE)

Loratio M. Pourzi

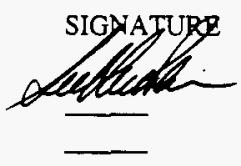

DATE

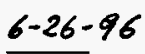

1. Is the Subject and/or Purpose clearly stated?

CIRCLE ONE

2. Are the required Input Data and their references and source (es) No provided and are they consistent with the Calc-note purpose:

3. Are the Assumptions clearly identified, valid, and consistent with the Calc-note purpose:

4. Are the Analytical Methods clearly identified?

5. Are all pages consecutively numbered and identified by the $\mathrm{Yeg}$ No calc-note number?

6. Is/are the version(s) of the computer program(s) used Yes No N/A identified?

7. Are input listings for all computer programs documented in this Yes No NTA calc-note?

8. Are the Results and Conclusions clearly stated?

9. Are all OUTPUT documents (if not part of the calculation) Yes No clearly referenced in the results section?

(es) No

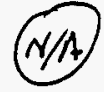

IF NO TO ANY OF THE ABOVE, SHEET NUMBER(S) WITH JUSTIFICATION:

REVIEWER'S NOTES (use additional pages as necessary)

Review method used: Alternate calculation_ Attached: $\mathrm{Y}_{-} \mathrm{N}_{-}$

Approximated Originator steps

Line By line otickido 
Calculation No. M-CLC-G-00234

Sheet No. 4 of 34

Rev. 0

Introduction:

Description of the Accident

This accident is initiated by an excavation in a Hanford Site pond, crib, or ditch. Ponds, cribs, and ditches were used at Hanford to dispose of liquid wastes. As a result these areas contain large quantities of contaminated soils.

Excavation in contaminated areas can cause the release radioactive and toxic materials to the environment through the generation and aerodynamic entrainment of respirable aerosols. An immediate release occurs when the soils are excavated followed by a continuous release due to resuspension by the wind.

This engineering calculation (EC) treats the contaminated soils in these facilities as if they were near the surface and easily exposed by a casual excavation. The fact is that these soils are buried under a large overburden of uncontaminated soils so that considerable excavation would have be performed before any contamination soils would be exposed. 
Calculation No. M-CLC.G.00234

Sheet No. 5 of 34

Rev. 0

\section{References:}

1. EPA, 1988, "Limiting Values of Radionuclide Intake and Air Concentration and Dose Conversion Factors for Inhalation, Submersion, and Ingestion", EPA-520/1-88-020, Federal Guidance Report No. 11, U. S. Environmental Protection Agency, Washington, DC.

2. Van Keuren, J. C. and A. V. Savino, 1996, "Tank Farm Compositions and Atmosphere Dispersion Coefficients for use in Safety Analysis Consequence Assessments", WHCSD-WM-SARR-016, Rev. 2, Westinghouse Hanford Company, Richland, Washington. (Final)

3. Waste Information Data System (WIDS), A database containing information about existing waste sites. Hard copy information from this database is available in Ref. 5.

4. DOE-HDBK-3010-94, 1994, "DOE Handbook Airborne Release Fractions/Rates and Restorable Fraction for Nonreactor Nuclear Facilities,", U.S. Department of Energy, Richland, Washington

5. DOE/RL-88-30, 1988, "Hanford Site Waste Management Units Repor, Rev. 4", U. S. Department of Energy, Richland, Washington (Attachment 1).

6. R. R. Lehrschall, 1992, "Safety assessment for Environmental Investigations and Site Characterizations, Volume 2 Aggregate Safety Assessment for Shallow/Near Surface Activities", WHC-SD-EN-SAD-016, Rev. 0, Westinghouse Hanford Company, Richland, Washington. 


\begin{tabular}{|l|}
\hline Calculation No. M-CLC-G-00234 \\
\hline Sheet No. 6 of 34 \\
\hline Rev. $\quad 0$ \\
\hline
\end{tabular}

\section{Input:}

- The radiological source term was derived from inventory 216-U-14 ditch, 216-U-16 crib, 216-U-17 crib, and 216-Z-20 crib (Ref. 3 and Attachment 2). The largest inventory is for Crib 216-Z-20 (see Excel spreadsheet in Appendix 1). Table 1 lists the main contributors to the source term. Inventory values in column 2 and column 3 are in both curies $(\mathrm{Ci})$ and bacqueral $(\mathrm{Bq})$. Effective Committed Dose Equivalent per Unit Intake (Inhalation) dose factors in seivert (Sv) per Bq are from Ref. 1. A general description of 216-Z-20 and its inventory is given in Ref. 5 (see Atttachment 1)

Table 1 216-Z-20 Crib Radioactive Inventory

\begin{tabular}{|c|c|c|c|c|}
\hline Isotope & $\begin{array}{c}\text { anventory } \\
\sin (\mathbf{C i})\end{array}$ & $\begin{array}{l}\text { Inventory } \\
\text { ( Bq) }\end{array}$ & $\begin{array}{l}\text { Dase Pactor } \\
\therefore(\mathbf{S v / B q})\end{array}$ & $\begin{array}{l}\text { Dose } \\
(\mathrm{Sv})\end{array}$ \\
\hline PU239 & $1.03 E+00$ & $3.81 E+10$ & $1.16 \mathrm{E}-04$ & $4.42 \mathrm{E}+06$ \\
\hline PU240 & $1.03 \mathrm{E}+00$ & $3.81 \mathrm{E}+10$ & $1.16 \mathrm{E}-04$ & $4.42 E+06$ \\
\hline PU241 & $2.17 \mathrm{E}+00$ & $8.03 E+10$ & 2.23E-06 & $1.79 E+05$ \\
\hline AM241 & $1.04 \mathrm{E}+00$ & $3.85 E+10$ & $1.20 \mathrm{E}-04$ & $4.62 \mathrm{E}+06$ \\
\hline Total & & & & $1.37 \mathrm{E}+07$ \\
\hline
\end{tabular}

- Toxicological Soil Concentrations - Hanford soils contain a number of nonradiological contaminants such as heavy metals and organic compounds. Concentrations of these substances in the Hanford Site soils are relatively low with concentrations measured in the parts per billion but have been found in parts per million range. A summary of controlling inorganic and organic contaminant concentrations that were derived from process analytical data of Hanford (Ref. 6, Attachment 3) The data is summarized in Table 2 below. 
Calculation No. M-CLC.G-00234

Sheet No. 7 of 34

Rev. 0

Table 2 Hazardous Organic and Inorganic Substances Anticipated in Hanford Soils

\begin{tabular}{|lcc|}
\hline & $\begin{array}{c}\text { Average Concentration } \\
\text { (part per billion) }\end{array}$ & $\begin{array}{c}\text { Maximum Concentration } \\
\text { (part per billion) }\end{array}$ \\
\hline Mercury & 1.21 & 20 \\
Lead & 28 & 319 \\
Chromium & 54 & 380 \\
Cyanide & 51 & 246 \\
Hydrazine & 59 & 88 \\
Carbon tetrachloride & 4,352 & 8,700 \\
Cyclohexane & 670 & 900 \\
Tetrachlorethane & 410 & 1,200 \\
Phenol & 37 & 80 \\
\hline
\end{tabular}

- The volume of contaminated soil in Crib $216-Z-20$ is $2400 \mathrm{~m}^{3}$. (Input Validation Form, Attachment 4)

- The volume of soil overburden for Crib $216-Z-20$ is $60,000 \mathrm{~m}^{3}$ (Input Validation Form, Attachment 4).

- Bounding Airborne Release Fractions (ARF), Airborne Release Rate (ARR), and Respirable Fractions (RF) for the suspension of falling powders and resuspension of powders was used in the analysis to bound the suspension of falling soils and resuspension soils is given in Table 3 (Ref. 4). 
Rev. 0

Table 3 Bounding ARFs and RFs for Suspension and Resuspension of Powders

\begin{tabular}{llll|} 
& & \\
Suspension of Falling Powders & 0.002 & 0.3 & 0.0006 \\
Homogeneous bed of powder & $(0.00004 / \mathrm{h})$ & 1.0 & $0.00004 / \mathrm{h}$ \\
exposed to nominal & & & \\
atmospheric conditions $(<2 \mathrm{~m} / \mathrm{s}$ & & \\
with gusts up to $20 \mathrm{~m} / \mathrm{s})$
\end{tabular}

- Onsite atmospheric dispersion coefficient $\chi / Q^{\prime}$ with plume meander $=0.0113 \mathrm{~s} / \mathrm{m}^{3}$. This value is used for release times greater than 2 hours (Ref. 2).

- Offsite atmospheric dispersion coefficient $\chi / Q^{\prime}$ with plume meander $=1.49 \times 10^{-5} \mathrm{~s} / \mathrm{m}^{3}$. This value is used for release time greater than 2 hours (Ref. 2)

- The breathing rate for time less than 12 hours is $3.3 \times 10^{-3} \mathrm{~m}^{3} / \mathrm{s}$ and $2.7 \times 10^{-3} \mathrm{~m}^{3} / \mathrm{s}$ for periods greater than 12 hours (Ref. 2). 
Calculation No. M-CLC.G-00234

Sheet No. 9 of 34

Rev. 0

\section{Assumptions:}

- The quantity of excavated material is bounded by an 12 hour excavation ( 1 shift) by a backhoe. The analysis assume that the backhoe removes 1 bucket of contaminated soil every 2 minutes. Based on a bucket size of $0.28 \mathrm{~m}^{3}$, the rate of excavation is estimated to be $10 \mathrm{~m}^{3} / \mathrm{hr}$ Attachment 4). This estimate is conservative since it is unlikely the excavation would continue uninterrupted for the entire shift.

- No credit is taken for uncontaminated overburden that must be excavated before reaching the contaminated crib soils. This is a conservation assumption since it will increase the volume of contaminated soils excavated.

- The average concentration of radiological and toxicological inventories in the crib are representative of the excavated material. This may not be the case since only 5 percent of the crib soils are excavated.

- It is conservatively assumed that the entire inventory contained in the excavated soils is subject to resuspension for a period of 24 hours from the start of the excavation. This is a very conservative assumption since only the soils near the surface of the dirt piles could be resuspended. 
Calculation No. M.CLC.G-00234

Sheet No. 10 of 34

Rev. 0

\section{Analytical Methods and Calculations:}

\section{Airborne Source Term}

The determination of the airborne source term follows that of Equation 1.1 in Ref. 4:

$$
Q=M A R \cdot D R \cdot A R F \cdot R F \cdot L P F
$$

where

$$
\begin{aligned}
& Q=\text { Source term } \\
& M A R=\text { Material at risk } \\
& \mathrm{DR}=\text { Damage ratio } \\
& \mathrm{ARF}=\text { Airborne release fraction } \\
& \mathrm{RF}=\text { Respirable fraction } \\
& \mathrm{LPF}=\text { Leakpath Factor }
\end{aligned}
$$

For aerodynamic entrainment/resuspension events, the airborne release rate (ARR) is given. It is multiplied by the time that the waste is subjected to the entrainment/resuspension mechanism to obtain the ARF.

\section{Material at Risk and Damage Ratio}

The excavation in cribs, ditches, or ponds accident analysis was conducted by using an accident scenario that bounds the material at risk in any excavation in one of these areas. The accident scenario postulates an excavation in $216-Z-20$ Crib by a backhoe. The backhoe excavates 1 bucket of contaminated soil every 2 minutes for a period of 12 hours resulting in approximately $120 \mathrm{~m}^{3}$ being excavated. Therefore,

$$
\operatorname{MAR}=120 \mathrm{~m}^{3}
$$

Since all of the excavated soils are assumed to come from the crib and not the overburden, $\mathrm{DR}=1$. 
Calculation No. M-CLC-G-00234

Sheet No. 11 of 34

Rev. 0

In the above scenario release and dispersion of airborne soil particles results from the successive dumping of contaminated soils and from the resuspension of contaminated soils by the wind. The ARF $x$ RF for falling powders from Table 3 is used to calculate the airborne source term for the dumping of crib soils and the ARR $\times$ RF for the resuspension of loose powders from Table 3 is used for the resuspension of soils by the wind.

Once the soils are aerosolized by the free fall spill or resuspended by the wind, they leak directly to the atmosphere, $\mathrm{LPF}=1$.

\section{Airborne Source Term}

Crib soils are excavated and dumped for $12 \mathrm{hr}$. Therefore, the airborne source term in liters (L) for the dumping of soils is

$$
\mathrm{Q}=120 \mathrm{~m}^{3} \cdot 1000 \frac{\mathrm{L}}{\mathrm{m}^{3}} \quad 0.0006 \cdot 1=72 \mathrm{~L}
$$

The airborne resuspension source term for an onsite receptor is

$$
\mathrm{Q}_{\text {susut }}^{\text {resus }}=60 \mathrm{~m}^{3} \cdot 1000 \frac{\mathrm{L}}{\mathrm{m}^{3}} \cdot 12 \mathrm{~h} \cdot \frac{0.00004}{\mathrm{~h}} \cdot 1=28.8 \mathrm{~L}
$$

Therefore,

$$
\mathrm{Q}_{\text {onsite }}=72 \mathrm{~L}+28.8 \mathrm{~L}=100.8 \mathrm{~L}
$$

The resuspension source term offsite is

$$
\mathrm{Q}_{\text {offsite }}^{\text {resus }}=120 \mathrm{~m}^{3} \cdot 1000 \frac{\mathrm{L}}{\mathrm{m}^{3}} \cdot 12 \mathrm{~h} \cdot \frac{0.00004}{\mathrm{~h}} \cdot \mathrm{I}+\mathrm{Q}_{\text {resum }}^{\text {reaw }}=86.4 \mathrm{~L}
$$

The offsite airborne source is

$$
Q_{\text {offsite }}=72 \mathrm{~L}+86.4 \mathrm{~L}=158.4 \mathrm{~L}
$$


Rev. 0

\section{Dose Consequence Analysis}

The radiological dose for spilling or resuspension of contaminated soils in $S v$ is given by (Ref. 2):

$$
D=Q \cdot \frac{\chi}{Q^{\prime}} \cdot R \cdot U L D
$$

where

$$
\begin{array}{ll}
Q & =\text { Quantity of respirable soil released }(\mathrm{L}) \\
\chi / Q & =\text { Atmosphere dispersion coefficient }\left(\mathrm{s} / \mathrm{m}^{3}\right) \\
\mathrm{R} & =\text { Breathing rate }\left(\mathrm{m}^{3} / \mathrm{s}\right) \\
\mathrm{ULD} & =\text { CEDE or maximum organ dose per unit liter inhaled }(\mathrm{Sv} / \mathrm{L})
\end{array}
$$

\section{Calculation of ULD for Soils}

An approximate ULD for excavated soils can be calculated using the expression:

$$
U L D=\frac{1}{V_{\text {Soti }}} \sum_{\text {isoopes }} C_{i} d c f_{i}
$$

where

$$
\begin{aligned}
& \mathrm{V}_{\text {Soil }}=\text { Volume of contaminated soil in crib }(\mathrm{L}) \\
& \mathrm{C}_{\mathrm{i}} \quad=\text { Crib inventory of radioactive isotope } \mathrm{i}(\mathrm{Bq}) \\
& \mathrm{dcf}_{\mathrm{i}} \quad=\text { Dose conversion factors }(\mathrm{Sv} / \mathrm{Bq}) \text { (Reference 1) }
\end{aligned}
$$

Using the isotopic concentrations and dose conversion factors from Table 2 gives 


\begin{tabular}{|l|}
\hline Calculation No. M-CLC.G-00234 \\
\hline Sheet No. 13 of 34 \\
\hline Rev. $\quad 0$ \\
\hline
\end{tabular}

$$
U D L_{\text {Soil }}=\frac{1.37 \cdot 10^{7} \mathrm{~Sv}}{2400 \mathrm{~m}^{3}\left(\frac{1000 L}{m^{3}}\right)}=5.71 \frac{S v}{L}
$$

\section{Atmospheric Dispersion Coefficients}

The atmospheric dispersion coefficients for both onsite and offsite receptors were calculated using the methods in Ref. 2 for release times of 12 and 24 hours are given in Table 4.

Table 4 Atmospheric Dispersion Coefficients

\section{Receptor Release Time (h) $\therefore$ with Plume Meander $\left(\mathrm{s} / \mathrm{m}^{3}\right)$}

$\begin{array}{ccc}\text { Onsite } & 12 & 0.00554 \\ \text { Offsite } & 24 & 4.6 \times 10^{-6}\end{array}$

\section{Radiological Dose Consequence}

Radiological dose consequences in milli-sievert ( $\mathrm{mSv}$ ) for onsite and offsite receptors are:

$$
\begin{aligned}
& D_{\text {onsite }}=100.8 L \cdot 0.00554 \frac{\mathrm{s}}{\mathrm{m}^{3}} \cdot 0.00033 \frac{\mathrm{m}^{3}}{\mathrm{~s}} \cdot 5.71 \frac{\mathrm{Sv}}{\mathrm{L}}=1.06 \mathrm{mSv} \\
& D_{\text {offsite }}=158.4 \mathrm{~L} \cdot 4.6 \times 10^{-6} \frac{\mathrm{s}}{\mathrm{m}^{3}} \cdot 0.00027 \frac{\mathrm{m}^{3}}{\mathrm{~s}} \cdot 5.71 \frac{\mathrm{Sv}}{\mathrm{L}}=1.13 \times 10^{-3} \mathrm{mSv}
\end{aligned}
$$


C'alculation No. M-CLC.G.00234

Sheet No. 14 of 34

Rev. 0

\section{Toxicological Dose Consequence}

Toxic chemicals are present in Hanford soils in the parts-per-million or parts-per-billion concentrations. Airborne concentrations of these chemicals due to excavation would be at most in parts-per-billion range. The toxicological consequence due to an excavation of the crib soils is therefore negligible. 
Calculation No. M-CLC-G-00234

Sheet No. 15 of 34

Rev. 0

\section{Results:}

The dose consequence results for an excavation in a TWRS pond, crib, or ditch are compared with the risk evaluation guidelines in Table 5. For the purpose of caparison with the guidelines, calculated doses are expressed in rem ( 1 rem $=0.1 \mathrm{mSv}$ ). 


\begin{tabular}{|l|}
\hline Call culation No. M.CLC-G.00234 \\
\hline Sheet No. 16 of 34 \\
\hline Rev. $\quad 0$ \\
\hline
\end{tabular}

Table 5 Radiological and Toxicological Dose Consequences for Excavation in Ponds, Cribs, or Ditches

Consequences: Within Risk Guidelines for an event in the anticipated category

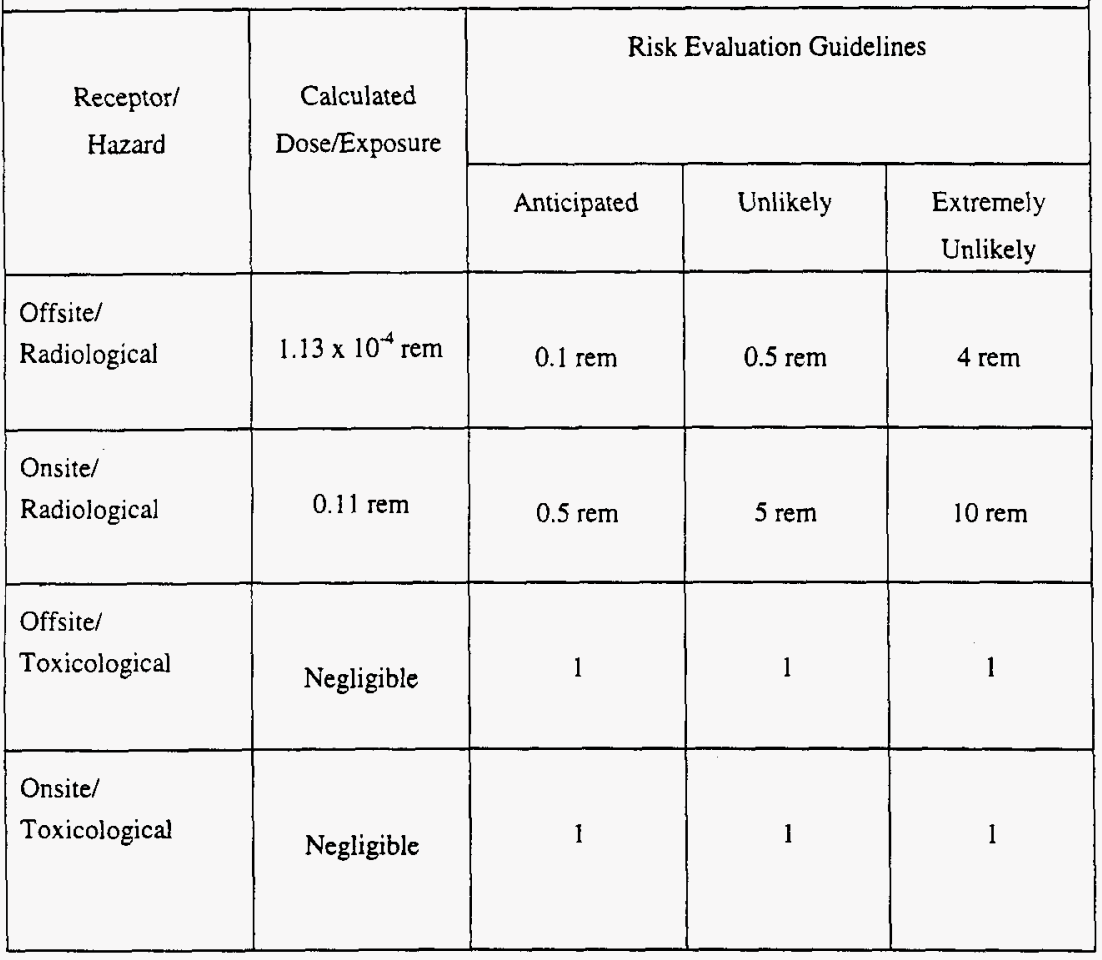


Calculation No. M-CLC-G-00234

Sheet No. 17 of 34

Rev. 0

\section{Conclusion:}

The calculated radiological and toxicological dose consequences for an excavation in a pond, crib, or ditch are well within the risk evaluation guidelines. Therefore this accident does not pose a significant risk and will not require implementation of any safety significant controls.

The calculated results can be affected by an increase in the amount of material excavated, a change in the radioactive inventory, or by the use of a more conservative value of the ARF or RF. However, since the calculated onsite dose is only 20 percent of the risk evaluation guideline value, even a substantial increase in these factors will not have a significant impact on the results.

\section{Appendices:}




\begin{tabular}{|l|}
\hline Calculation No. M-CLC-G-00234 \\
\hline Sheet No. 18 of 34 \\
\hline Rev. $\quad 0$ \\
\hline
\end{tabular}

Appendix 1 Unit Liter Doses for Ponds, Cribs, or Ditches

\section{Ponds, Cribs, and Ditches}

\begin{tabular}{|c|c|c|c|c|c|c|c|c|c|c|c|c|c|}
\hline $\mathrm{Ci}$ & $3.70 \mathrm{E}+10$ & $\mathrm{~Bq}$ & & & & & & & & & & & \\
\hline V & $2.40 E+06$ & liter & & & & & & & & & & & \\
\hline & & & & & & & & & & $\begin{array}{c}\text { Dose } \\
(\mathrm{Sv} / \mathrm{L})\end{array}$ & $\begin{array}{c}\text { Dose } \\
(\mathrm{Sv} / \mathrm{L})\end{array}$ & $\begin{array}{c}\text { Dose } \\
(\mathrm{Sv} / \mathrm{L})\end{array}$ & \\
\hline Isotope & $\begin{array}{l}\text { Crib Inv. } \\
\text { 216-Z-20 } \\
\text { (Ci) }\end{array}$ & $\begin{array}{c}\text { Crib Inv. } \\
\text { (Bq) }\end{array}$ & $\begin{array}{c}\text { Ditch } \\
\text { 216-U-14 } \\
\text { (Ci) }\end{array}$ & $\begin{array}{c}\text { Ditch } \\
\text { Inv. }(\mathbf{B q})\end{array}$ & $\begin{array}{l}\text { Crib Inv. } \\
\text { 216-U-16 } \\
\text { (Ci) }\end{array}$ & $\begin{array}{c}\text { Crib Inv. } \\
(\mathbf{B q})\end{array}$ & $\begin{array}{l}\text { Crib Inv } \\
\text { 216-U-17 } \\
\text { (Ci) }\end{array}$ & $\begin{array}{c}\text { Crib Inv. } \\
\text { (Bq) }\end{array}$ & Z-20 & U-14 & U-16 & U-17 & $\begin{array}{c}\text { Dose } \\
\text { Factor } \\
\text { Sv/Bq }\end{array}$ \\
\hline $\mathrm{CO} 60$ & $2.99 \mathrm{E}-03$ & $1.11 \mathrm{E}+08$ & $4.96 \mathrm{E}-04$ & $1.84 \mathrm{E}+07$ & $0.00 \mathrm{E}+00$ & $0.00 \mathrm{E}+00$ & & $0.00 \mathrm{E}+00$ & $2.72 \mathrm{E}-06$ & $4.52 \mathrm{E}-07$ & $0.00 \mathrm{E}+00$ & $0.00 \mathrm{E}+00$ & $5.91 \mathrm{E}-08$ \\
\hline SE79 & $1.63 \mathrm{E}-07$ & $6.03 E+03$ & $1.87 \mathrm{E}-06$ & $6.92 \mathrm{E}+04$ & $6.56 \mathrm{E}-09$ & $2.43 \mathrm{E}+02$ & & $0.00 \mathrm{E}+00$ & $6.68 \mathrm{E}-12$ & $7.67 \mathrm{E}-11$ & $2.69 \mathrm{E}-13$ & $0.00 \mathrm{E}+00$ & $2.66 \mathrm{E}-09$ \\
\hline SR90 & $9.22 \mathrm{E}-02$ & $3.41 \mathrm{E}+09$ & $5.88 \mathrm{E}-02$ & $2.18 \mathrm{E}+09$ & $8.17 \mathrm{E}-03$ & $3.02 E+08$ & $5.70 \mathrm{E}-06$ & $2.11 \mathrm{E}+05$ & $9.20 \mathrm{E}-05$ & $5.87 \mathrm{E}-05$ & 8.15E-06 & $5.69 \mathrm{E}-09$ & $6.47 \mathrm{E}-08$ \\
\hline Y90 & $8.86 \mathrm{E}-02$ & $3.28 \mathrm{E}+09$ & 5.77E-02 & $2.13 E+09$ & $8.18 \mathrm{E}-03$ & $3.03 E+08$ & & $0.00 \mathrm{E}+00$ & $3.11 \mathrm{E}-06$ & $2.03 \mathrm{E}-06$ & $2.88 \mathrm{E}-07$ & $0.00 \mathrm{E}+00$ & $2.28 \mathrm{E}-09$ \\
\hline ZR93 & $2.11 \mathrm{E}-06$ & $7.81 \mathrm{E}+04$ & $2.41 \mathrm{E}-05$ & $8.92 \mathrm{E}+05$ & $8.48 \mathrm{E}-08$ & $3.14 \mathrm{E}+03$ & & $0.00 \mathrm{E} i 00$ & $2.08 \mathrm{E}-10$ & 2.37E-09 & $8.35 \mathrm{E}-12$ & $0.00 \mathrm{E}+00$ & $6.39 \mathrm{E}-09$ \\
\hline TC99 & $9.39 \mathrm{E}-06$ & $3.47 \mathrm{E}+05$ & $1.72 \mathrm{E}-01$ & $6.36 \mathrm{E}+09$ & $3.77 \mathrm{E}-07$ & $1.39 \mathrm{E}+04$ & $1.26 \mathrm{E}-03$ & $4.66 \mathrm{E}+07$ & $4.01 \mathrm{E}-11$ & $7.35 \mathrm{E}-07$ & $1.61 \mathrm{E}-12$ & $5.38 \mathrm{E}-09$ & $2.77 \mathrm{E}-10$ \\
\hline RU106 & $5.16 \mathrm{E}-06$ & $1.91 \mathrm{E}+05$ & $4.44 \mathrm{E}-12$ & $1.64 \mathrm{E}-01$ & $5.16 \mathrm{E}-07$ & $1.91 E+04$ & & $0.00 \mathrm{E}+00$ & $1.03 \mathrm{E}-08$ & $8.83 \mathrm{E}-15$ & $1.03 E-09$ & $0.00 \mathrm{E}+00$ & $1.29 \mathrm{E}-07$ \\
\hline RH106 & $5.16 \mathrm{E}-06$ & $1.91 \mathrm{E}+05$ & 4.44E- 12 & $1.64 \mathrm{E}-01$ & $5.16 \mathrm{E}-07$ & $1.91 \mathrm{E}+04$ & & $0.00 \mathrm{E}+00$ & $4.59 \mathrm{E}-12$ & $3.95 \mathrm{E}-18$ & $4.59 \mathrm{E}-13$ & $0.00 \mathrm{E}+00$ & $5.77 \mathrm{E}-11$ \\
\hline PD107 & 2.77E-08 & $1.02 \mathrm{E}+03$ & $3.16 \mathrm{E}-07$ & $1.17 E+04$ & $1.11 \mathrm{E}-09$ & $4.11 \mathrm{E}+01$ & & $0.00 \mathrm{E}+00$ & $2.96 \mathrm{E}-14$ & $3.38 \mathrm{E}-13$ & $1.19 \mathrm{E}-15$ & $0.00 \mathrm{E}+00$ & $6.94 \mathrm{E}-11$ \\
\hline CD113M & $9.29 \mathrm{E}-10$ & $3.44 \mathrm{E}+01$ & $4.22 \mathrm{E}-09$ & $1.56 \mathrm{E}+02$ & $3.76 \mathrm{E}-11$ & $1.39 \mathrm{E}+00$ & & $0.00 \mathrm{E}+00$ & $6.46 \mathrm{E}-12$ & $2.93 \mathrm{E}-11$ & $2.61 \mathrm{E}-13$ & $0.00 \mathrm{E}+00$ & 4.51E-07 \\
\hline
\end{tabular}




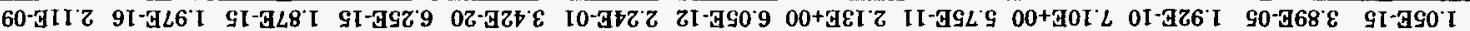

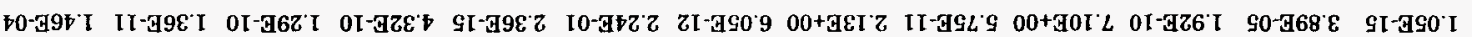

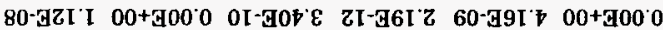

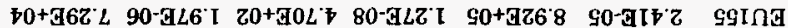

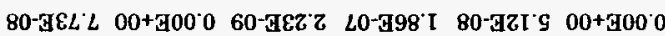

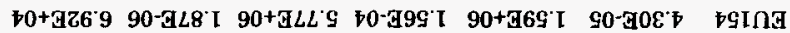

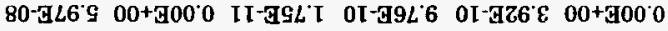

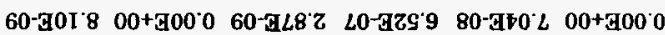

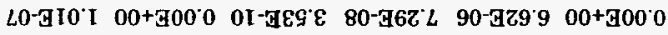
$00+900000+300000+900000+300000+300000+$ G00 0

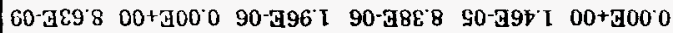

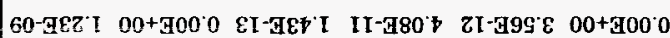

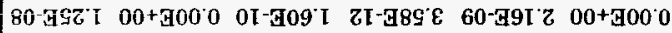

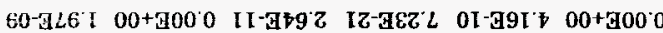

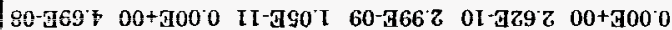

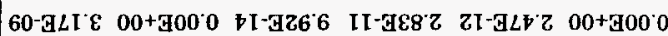

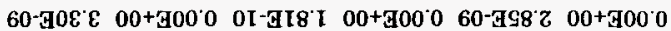

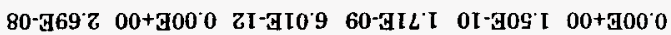

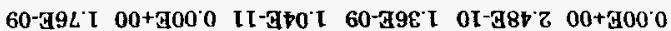

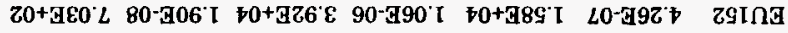

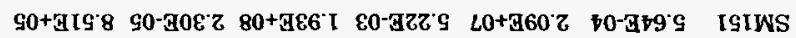

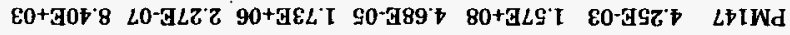

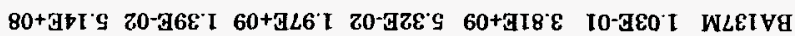

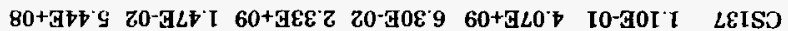

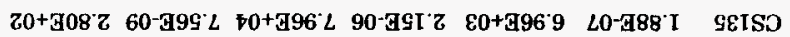

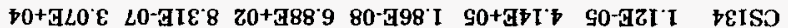

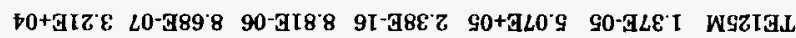

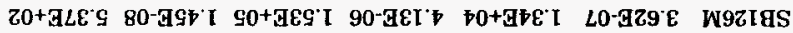

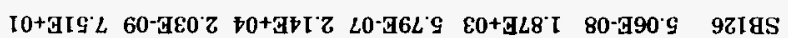

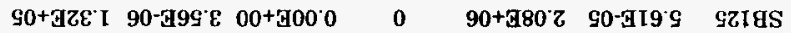

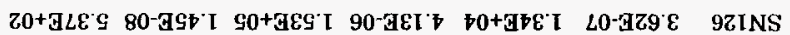

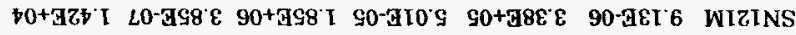
的

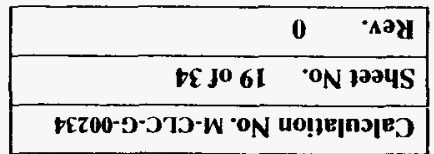




\begin{tabular}{|l|}
\hline Calculation No. M-CLC.G-00234 \\
\hline Sheet No. 20 of 34 \\
\hline Rev. $\quad 0$ \\
\hline
\end{tabular}

\begin{tabular}{|c|c|c|c|c|c|c|c|c|c|c|c|c|c|}
\hline RA226 & $1.06 \mathrm{E}-15$ & $3.92 \mathrm{E}-05$ & $1.93 \mathrm{E}-10$ & $7.14 \mathrm{E}+00$ & $5.76 \mathrm{E}-11$ & $2.13 \mathrm{E}+00$ & $6.05 \mathrm{E}-12$ & $2.24 \mathrm{E}-01$ & $3.79 \mathrm{E}-17$ & $6.90 \mathrm{E}-12$ & $2.06 \mathrm{E}-12$ & $2.16 \mathrm{E}-13$ & $2.32 \mathrm{E}-06$ \\
\hline U233 & 2.92E-12 & $1.08 \mathrm{E}-01$ & 6.39E-02 & $2.36 \mathrm{E}+09$ & $6.63 \mathrm{E}-13$ & $2.45 \mathrm{E}-02$ & & $0.00 \mathrm{E}+00$ & $1.65 \mathrm{E}-12$ & $3.61 \mathrm{E}-02$ & $3.74 \mathrm{E}-13$ & $0.00 \mathrm{E}+00$ & $3.66 \mathrm{E}-05$ \\
\hline U234 & 2.63E-07 & $9.73 \mathrm{E}+03$ & & $0.00 \mathrm{E}+00$ & 0 & $0.00 \mathrm{E}+00$ & $1.51 \mathrm{E}-16$ & $5.59 \mathrm{E}-06$ & $1.45 \mathrm{E}-07$ & $0.00 \mathrm{E}+00$ & $0.00 \mathrm{E}+00$ & 8.33E-17 & $3.58 \mathrm{E}-05$ \\
\hline U235 & $1.01 \mathrm{E}-08$ & $3.74 E+02$ & $6.30 \mathrm{E}-13$ & 2.33E-02 & $4.44 \mathrm{E}-10$ & $1.64 \mathrm{E}+01$ & $1.46 \mathrm{E}-13$ & $5.40 \mathrm{E}-03$ & $3.07 \mathrm{E}-10$ & $1.91 \mathrm{E}-14$ & $1.35 \mathrm{E}-11$ & $4.43 \mathrm{E}-15$ & $1.97 \mathrm{E}-06$ \\
\hline PU238 & 2.30E-02 & $8.51 E+08$ & 0 & $0.00 \mathrm{E}+00$ & 0 & $0.00 \mathrm{E}+00$ & $1.14 \mathrm{E}-03$ & $4.22 E+07$ & $3.76 \mathrm{E}-02$ & $0.00 \mathrm{E}+00$ & $0.00 \mathrm{E}+00$ & $1.86 \mathrm{E}-03$ & $1.06 \mathrm{E}-04$ \\
\hline PU239 & $1.03 \mathrm{E}+00$ & $3.81 \mathrm{E}+10$ & $8.00 E-05$ & $2.96 \mathrm{E}+06$ & $4.50 \mathrm{E}-02$ & $1.67 \mathrm{E}+09$ & $1.48 \mathrm{E}-05$ & $5.48 \mathrm{E}+05$ & $1.84 E+00$ & $1.43 \mathrm{E}-04$ & $8.05 \mathrm{E}-02$ & 2.65E-05 & $1.16 \mathrm{E}-04$ \\
\hline PU240 & $1.03 \mathrm{E}+00$ & $3.81 \mathrm{E}+10$ & 8.00E-05 & $2.96 \mathrm{E}+06$ & 4.50E-02 & $1.67 \mathrm{E}+09$ & $1.48 \mathrm{E}-05$ & $5.48 \mathrm{E}+05$ & $1.84 \mathrm{E}+00$ & $1.43 \mathrm{E}-04$ & 8.05E-02 & 2.65E-05 & $1.16 \mathrm{E}-04$ \\
\hline PU241 & $2.17 \mathrm{E}+00$ & $8.03 E+10$ & 0 & $0.00 \mathrm{E}+00$ & 0 & $0.00 \mathrm{E}+00$ & & $0.00 \mathrm{E}+00$ & $7.46 \mathrm{E}-02$ & $0.00 \mathrm{E}+00$ & $0.00 \mathrm{E}+00$ & $0.00 \mathrm{E}+00$ & $2.23 \mathrm{E}-06$ \\
\hline AM241 & $1.04 \mathrm{E}+00$ & $3.85 \mathrm{E}+10$ & $2.88 \mathrm{E}-04$ & $1.07 \mathrm{E}+07$ & 2.31E-01 & $8.55 \mathrm{E}+09$ & $7.85 \mathrm{E}-05$ & $2.90 \mathrm{E}+06$ & $1.92 \mathrm{E}+00$ & 5.33E-04 & $4.27 \mathrm{E}-01$ & $1.45 \mathrm{E}-04$ & $1.20 \mathrm{E}-04$ \\
\hline AM242M & $0.00 E+00$ & $0.00 \mathrm{E}+00$ & 0 & $0.00 \mathrm{E}+00$ & 0 & $0.00 \mathrm{E}+00$ & & $0.00 \mathrm{E}+00$ & $0.00 \mathrm{E}+00$ & $0.00 \mathrm{E}+00$ & $0.00 \mathrm{E}+00$ & $0.00 \mathrm{E}+00$ & $1.15 \mathrm{E}-04$ \\
\hline AM243 & $0.00 \mathrm{E}+00$ & $0.00 \mathrm{E}+00$ & 0 & $0.00 \mathrm{E}+00$ & 0 & $0.00 \mathrm{E}+00$ & & $0.00 \mathrm{E}+00$ & $0.00 \mathrm{E}+00$ & $0.00 \mathrm{E}+00$ & $0.00 \mathrm{E}+00$ & $0.00 \mathrm{E}+00$ & $1.19 \mathrm{E}-04$ \\
\hline CM242 & $0.00 \mathrm{E}+00$ & $0.00 \mathrm{E}+00$ & 0 & $0.00 \mathrm{E}+00$ & 0 & $0.00 \mathrm{E}+00$ & & $0.00 \mathrm{E}+00$ & $0.00 \mathrm{E}+00$ & $0.00 \mathrm{E}+00$ & $0.00 \mathrm{E}+00$ & $0.00 \mathrm{E}+00$ & 4.67E-06 \\
\hline CM244 & $0.00 \mathrm{E}+00$ & $0.00 \mathrm{E}+00$ & 0 & $0.00 \mathrm{E}+00$ & 0 & $0.00 \mathrm{E}+00$ & & $0.00 \mathrm{E}+00$ & $0.00 \mathrm{E}+00$ & $0.00 \mathrm{E}+00$ & $0.00 \mathrm{E}+00$ & $0.00 \mathrm{E}+00$ & $6.70 \mathrm{E}-05$ \\
\hline EU155 & $2.41 E-05$ & $8.92 \mathrm{E}+05$ & $1.27 \mathrm{E}-08$ & $4.70 \mathrm{E}+02$ & $1.97 \mathrm{E}-06$ & $7.29 \mathrm{E}+04$ & & $0.00 \mathrm{E}+00$ & $4.16 \mathrm{E}-09$ & $2.19 \mathrm{E}-12$ & $3.40 \mathrm{E}-10$ & $0.00 \mathrm{E}+00$ & $1.12 \mathrm{E}-08$ \\
\hline ULD & & & & & & & & & $5.72 \mathrm{E}+00$ & & & & \\
\hline
\end{tabular}


Sheet No. 21 of 34

Rev. 0

Attachments:

Attachment 1 General Description of Crib 216-Z-20 
WHC-SD-WM-CN-053 REV 0

hment 1 .

$D O E / R L-B 8-30$, REV. 4

M- CLC- C-00234

Sheet 22 of 34

UMIT NAME: $216-2-20$

UNIT TYPE: CYIb

HASTE CATEGORY: Low-Level Haste

OPERABLE UNIT: 200-UP-2

SWMU: Yes

UNIT STATUS: ACtive

START DATE: September 24, 1981

COOROINATES: $N 37830$ W76523, N39280 W76130 (centerifine)

WASTE TYPES AND AMOUNTS: The site has been receiving cooling water, steam condensäte, stori sewer, bullding drains, HEDL RADTU couling water, and chemical drains waste from the 234-5Z Building; cooling water sleam condensate and laboratory drains from the 231-2 Bullding; and miscellaneous drains. Waste from 291-2, 232-2, and $236-2$ buildings. The unit will al so receive wastes from 2736-2 Building, which is now under construction (Project B-245).

SITE DESCRIPTION: The structure has varied depths of 9 to $29 \mathrm{ft}$ below ground surface. Three $6-i n$. perforated PVC distribution pipes are located $3.5 \mathrm{ft}$ apart along the length to within $1 \mathrm{ft}$ of the south end, where the plpes are capped. A set of 3 risers stem from the distribution pipes, rising to $1.5 \mathrm{ft}$ above grade at 4 locations throughout the unit. $-57,150 \mathrm{cu} f t$ of $0.5-i n$. to 2.5-in. gravel fill is backfilled over with soil. The side slope is 1:2.

KNOWH RELEASES: On February 2, 1986, a release of $0.02 \mathrm{UCI} / \mathrm{L}$ alpha (amount unknown) occurred to this unit from 234-52 Building tank leakage. On December 20 , 1984, a release of 107 UC $1 / L$ unknown radionuci ides (amount unknown)

occurred to this unit from 234-5Z Bulloing tank leakage. This unit received a splli of 7,594 ib of nitric acid on september $26,1984$. 
Calculation No. M-CLC-G-00234

Sheet No. 23 of 34

Rev. 0

Attachment 2 Cumulative Decayed Inventory Report 


$$
\begin{gathered}
M-C h C-G-\sigma 0=34, R Q V .0 \\
\text { Sheet } 24 \text { of } 34
\end{gathered}
$$

$05 / 06 / 96$

CUMULATIVE DECAYED INVENTORY REPORT

Site \# 155: 216-U-14 DITCH (In CWM, 216-U-10)

$13: 09$

Active from $03 / 01 / 52$ to $12 / 31 / 94$

Cumulative Waste Volume $1.22 \mathrm{E}+09$ Liters

\begin{tabular}{|c|c|c|c|}
\hline & I sotope & $\mathrm{Halfl} 1 \mathrm{fe}$ & Curies \\
\hline & $\begin{array}{ll}H-3 \\
H-\infty\end{array}$ & 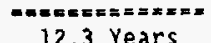 & $==x=-x=x$ \\
\hline & $C_{0-60}$ & 5.27 Years & $<4.96 \mathrm{E}-04$ \\
\hline & $\mathrm{Se}-79$ & $6.5 E+4$ Years & $1.87 \bar{E}-06$ \\
\hline & $5 r-90$ & 29.12 Years & $5.88 \mathrm{E}-02$ \\
\hline & $Y-90$ & 65 Hours & $<5.77 \mathrm{E}-02$ \\
\hline & $2 r-93$ & $-5 E+6$ Years & $2.41 E-05$ \\
\hline & $T C-99$ & $2.13 E+5$ Years & -01 \\
\hline 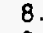 & $R u-106$ & 358 Days & -12 \\
\hline 9. & $R h-106$ & 30 Seconds & -12 \\
\hline 10 & $P d-107$ & $7 E+6$ Years & .07 \\
\hline 11. & $C d-113 M$ & 5.1 Years & -09 \\
\hline 12. & $5 n-121 M$ & 27.5 Hours & -05 \\
\hline 3. & $511-126$ & 70 Minutes & $4.13 E-06$ \\
\hline 14 & $50-126$ & 9 Hours & $5.79 \mathrm{E}-07$ \\
\hline & $S U-126 M$ & 19 Minutes & $4.13 E-06$ \\
\hline . & $\mathrm{Te}-125 \mathrm{M}$ & 58 Days & $2.38 E-16$ \\
\hline & $C 5-134$ & 2.1 Years & $1.86 E-08$ \\
\hline 10. & $C s-135$ & $2.9 E+6$ Years & $2.15 E-06$ \\
\hline 10 & $C 5-137$ & 30 Years & $6.30 E-02$ \\
\hline 60 & $B a-137 M$ & 2.6 Minutes & $E-02$ \\
\hline & $\mathrm{Ce}-144$ & 284 Days & $1.51 E-15$ \\
\hline 8.2 & $\operatorname{Pr}-144$ & 17 Minutes & $2.16[-17$ \\
\hline 23. & $P m-147$ & 2.6 Years & $4.68 E-05$ \\
\hline & $5 n !-151$ & 70 Years & $5.22 E-03$ \\
\hline . & $E u-152$ & 13.3 Years & $1.06 \mathrm{E}-06$ \\
\hline 26. & $E u-154$ & 8.8 Years & 1. $56 \mathrm{E}-04$ \\
\hline & $E u-155$ & 4.96 Years & $1.27 E-08$ \\
\hline 28. & $T 1-208$ & 3.1 Minutes & $2.92 E-18$ \\
\hline & B 1-212 & 60.55 Minutes & -18 \\
\hline & $B 1-214$ & 19.9 Minutes & 10 \\
\hline & $\mathrm{Pb}-212$ & 10.64 Hours & -18 \\
\hline & $\mathrm{Pb}-214$ & 26.8 Minutes & -10 \\
\hline & $P u-212$ & 3.1E-7 Seconds & $5.20 E-18$ \\
\hline & $\mathrm{PO}-216$ & 0.15 Seconds & 8.1 \\
\hline & $R n-220$ & 55.6 Seconds & B. 1 \\
\hline & $R a-224$ & 3.66 Days & 8.11 \\
\hline & $R a-226$ & 1,600 Years & 1.93 \\
\hline 38. & $A C-228$ & 6.13 Hours & $7.27 E-17$ \\
\hline & $T h-232$ & $1.41 E+10$ Years & $4.12 E-15$ \\
\hline 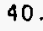 & U (Gross) & 4. $5 E+9$ Years* & $6.39 E-02$ \\
\hline & $U-233$ & $1.62 E+5$ Years & 6.60 \\
\hline & $U-235$ & $7.04 E+8$ Years & 6.30 \\
\hline & $\mathrm{Pu}-239 / 40$ & 24,131 Years & $1.60 E-04$ \\
\hline & $A \mid l 1-24 !$ & 432 Years & $2.88 E-04$ \\
\hline & Total $\alpha$ & $n<a$ & -02 \\
\hline
\end{tabular}

Radionuclides decayed to $12 / 31 / 94$ 
M- ChS-G-0.23Y, Rov.C

Sheet 25 of 34

1

$05 / 06 / 96$

CUMULATIVE OECAYED INVENTORY REPORT

Site "155: 216-U-14.DITCH (In CWM, 216-U-10)

Page 2

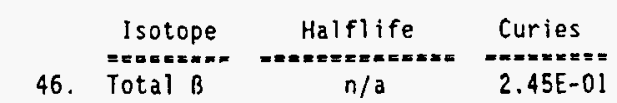

- The halfilfe shown for Total Uranium is the halfiffe of U-238. The halfi ife shown for mixed Plutonfum-239/40 is the halflife of Pu-239. 
WHC-SD-WM-CN-053 REV 0

\section{M-CLC-G-00234, Rew. O Sheet 26 of 34}

$05 / 06 / 96$

CUMULATIVE DECAYED INVENTORY REPORT

Site \#176: 216-2-20 CRIB

Active from $09 / 24 / 8$ ! to $12 / 31 / 94$

Cumulative waste Volume $4.45 \mathrm{E}+09$ Liters

Radionuclides decayed to $12 / 31 / 94$

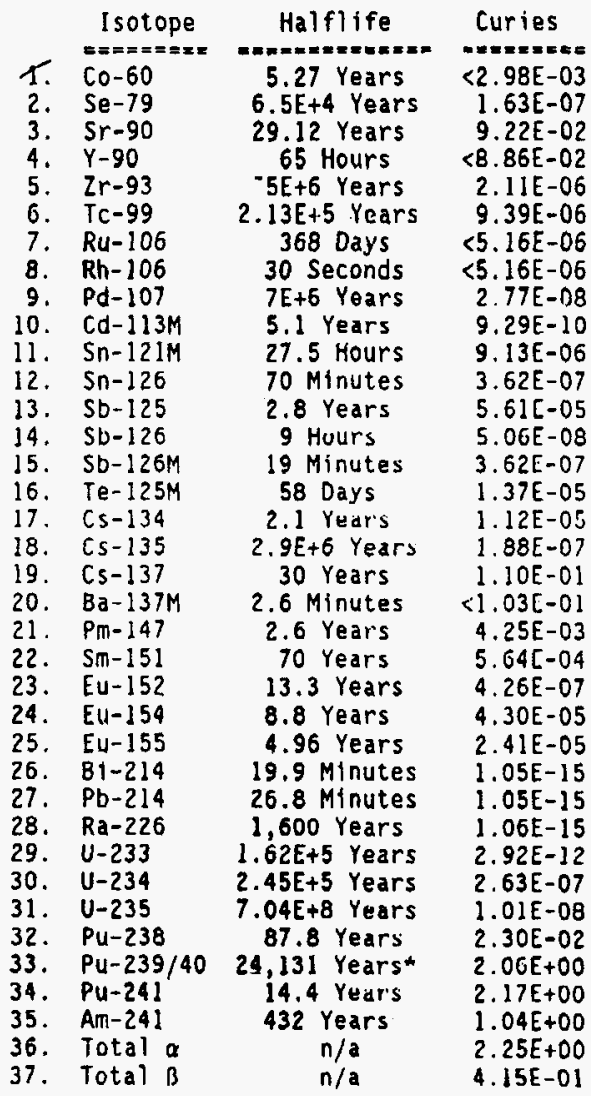

- The halflife shown for Total Uranium is the halflife of U-238. The halflife shuwn for mixed Plutonium-239/40 is the halflife of Pu-239.

$+^{\wedge}\left[\$ 100^{\wedge}\left[\left(10 U^{\wedge}[(\right.\right.\right.$ sop $12.00 h] 0.0$ Vos0b3T^[2a12L^[\$160 
CUMULATIVE DECAYED IRVENTORY REPORT

$$
\begin{aligned}
& \text { M-ChC-G-0 o } 2>4 \text {, Rev. } 0 \\
& \text { Sleet } 27 \text { of } 34
\end{aligned}
$$

$05 / 06 / 96$

Site \#158: 216-U-17 CRIB

$13: 10$

Active from $01 / 31 / 88$ to $12 / 31 / 94$

Cumulative Waste volume $5.90 \mathrm{E}+06$ Liters

\begin{tabular}{|c|c|c|c|}
\hline & Isotope & Halflife & Curies \\
\hline 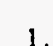 & $\begin{array}{l}-2=200=20= \\
H-3\end{array}$ & 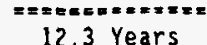 & $=m=-10-1=0$ \\
\hline & $5 r-90$ & 29.12 Years & $5.70 E-06$ \\
\hline & Tc-99 & $2.13 E+5$ Years & $E-03$ \\
\hline 4 & $B i-214$ & 19.9 Minutes & 12 \\
\hline 5. & $\mathrm{~Pb}-214$ & 26.8 Minutes & \\
\hline & $R a-226$ & 1,600 Years & -12 \\
\hline & $A C-228$ & 6.13 Hours & 18 \\
\hline 0 & Th-232 & $1.41[+10$ Years & -16 \\
\hline & $U$ (Gross) & 4.5E+9 Years & \\
\hline 10 & $U-233$ & $1.62 E+5$ Years & 16 \\
\hline 11 & $U-235$ & $7.04 E+8$ Years & \\
\hline 13 & $\begin{array}{ll}P u-239 / 40 \\
A m-241\end{array}$ & 24,131 Years* & 05 \\
\hline & Total a & $n / a$ & 04 \\
\hline & jot & $n / a$ & -03 \\
\hline
\end{tabular}

Radionuclides decayed to $12 / 31 / 94$

* The halflife shown for Total Uranium is the halflife of U-238. The halfl ife shown ror nixed Plutonium-239/40 is the halflife or Pu-239. 
WHC-SD-WM-CN-053 REV 0

$$
\begin{aligned}
& \text { M-che- G-00234, Rar. } 0 \\
& \text { Sheet } 28 \text { of } 34
\end{aligned}
$$

$05 / 06 / 96$

CUMULATIVE DECAYEO INVENTORY REPORT

Site \# 157: 216-U-16 CRIB

Active from $09 / 01 / 84$ to $02 / 28 / 85$

Cumulative Waste Volume $4.09 E+08$ Liters

Radionuclides decayed to $12 / 31 / 94$

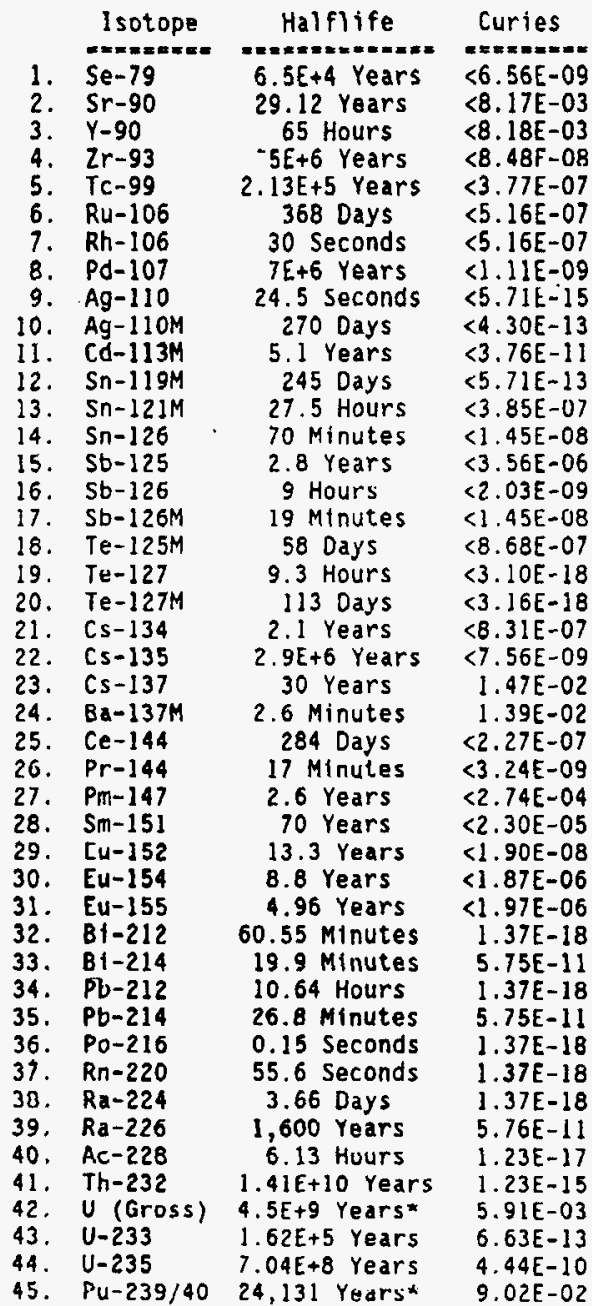


WHC-SD-WM-CN-053 REV D

$$
\begin{aligned}
& \text { M.CLC-G-00234, Rew. } \\
& \text { Sheet } 29 \text { of } 34
\end{aligned}
$$

1

$05 / 06 / 96$

CUMULATIVE DECAYED INVENTORY REPORT

Site \# 157: 216-U-16 CRIB
Isotope
Halflife

Page 2

* The halflife shown for Total Uranium is the halflife of U-238. The halflife shown for mixed Plutonium-239/40 is the halflife of Pu-239. 


WHC-SD-WM-CN-053 REV 0
\begin{tabular}{|l|} 
Calculation No. M-CLC-G-00234 \\
\hline Sheet No. 30 of 34 \\
\hline Rev. $\quad 0$ \\
\hline
\end{tabular}

Attachment 3 Hazardous Organic and Inorganic Substances Anticipated in Hanford Soils 
WHC-SD-WM-CN-053 REV O M-CLC- 6-00234, ReV.O
Sheat 31 of 34

WHC-SD-EN-SAD-016, REV O-C

VOLUME 2

Table 2. Hazardous Organic and Inorganic Substances

Anticipated in Hanford Solls.

\begin{tabular}{l|c|c}
\hline \multicolumn{1}{c|}{ Analyte } & $\begin{array}{c}\text { Average } \\
\text { concentration } \mathrm{p} / \mathrm{b}\end{array}$ & $\begin{array}{c}\text { Maximum } \\
\text { concentration } \mathrm{p} / \mathrm{b}\end{array}$ \\
\hline Mercury & 1.28 & 20 \\
\hline Lead & 28 & 319 \\
\hline Chromium & 54 & 380 \\
\hline Cyanide & 51 & 246 \\
\hline Hydrazine & 59 & 88 \\
\hline Carbon tetrachloride & 4,352 & 8,700 \\
\hline Cyclohexane & 670 & 900 \\
\hline Tetrachloroethane & 410 & 1,200 \\
\hline Phenol & 37 & 80 \\
\hline
\end{tabular}

For most of the shallow/near surface sampling activities, the potential hazard inventory consists of the material sample volume that in most cases is less than one L. The methods (e.g., hand tools) used to obtain these samples generally do not provide sufficient energy for generating source term to uninvolved individuals.

Excluding mechanized excavation sampling, mechanisms for generating a source term are not available in the shallow/near surface sampling activities. In the case of mechanfzed soll, sampling, where there are relatively large volumes of dirt $\left[>1 \mathrm{~m}^{3}\left(0.3 \mathrm{ft}^{3}\right)\right]$, potentlally contaminated soll can be brought to the surface, and exposure to wind or other dispersal mechanisms can occur. Any mechanized soll gas sampling could potentially result in small

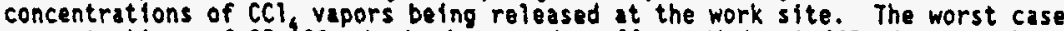
concentrations of $25,000 \mathrm{p} / \mathrm{m}$ (under static well conditions) $\mathrm{CCl}_{4}$ detected has been at the $216-Z$ Crib sites in the 200 West Area. categories:

The shallow/near surface sampling activities can be segregated into five

1. Nonintrustre/nonaccumulative (soll gas. sampling, radiological surveys, etc.). Based on the lack of a material hazard, the activities fitting this description are excluded from safety review requirements.

2. Intrusfve/accumul at ive sampling (mechanized or nonmechantzed), where no contauthants are anticipated. Based on the lack of a material hazard, the activities fitting this description are excluded from safety review requirements.

3. Nonmechanized intrusive/accumulative sampling where the small volumes (measured in $L$ ) of accumulated material exceed the release criteria provided in WHC-CM-4-10, Section 11.4.6. 
Calculation No. M-CLC-G-00234

Sheet No. 32 of 34

Rev. 0

Attachment 4 Input Validation Form 


$$
\begin{aligned}
& \text { WHC-SD-WM-CN-053 REV } 0 \\
& \text { M-CLC-G- } 00234 \text {, Revo } \\
& \text { Sheet } 33 \text { of } 34
\end{aligned}
$$

Tracking " RDG,2

\begin{tabular}{|l|l|l|}
\hline $\begin{array}{l}\text { Neme of Originator } \\
\text { Rondd D. Graves }\end{array}$ & $\begin{array}{l}\text { Organization or Team 2 } \\
\text { WSRC FSAR TEAM }\end{array}$ & $\begin{array}{l}\text { Date } \\
4 / 29 / 96\end{array}$ \\
\hline
\end{tabular}

Statement of Problem: This accident involves the inadvertent cxcyvation of a crib, ditch, or pond. The prain unceraintiesin che analysis is the material at risk (MAR) end the concentration of radionuclides and sooradiological cbemieal in the excavated soil.

(1) It is assumed that the quantliy of material excevated ls bounded by an excavation by a backhoe that excavates I bucket, approxinately $0.28 \mathrm{~m}^{\prime}$ every 2 sidutes (10 $\mathrm{m} / \mathrm{hr}$. is used in the analysis). The excavation last ove 12 hour shift.

(2) The radiological coucentration is the excavaled soil is bounded the sadiological conecutration in BY Cribs as represented by soils under $200-\mathrm{BP}-1 \mathrm{crib}$.

(3) It is assumed that the loxilogical soure lem is bounded by the summary of controlling inorgauic aud orgauic conpound

\begin{tabular}{|c|c|c|c|}
\hline \multicolumn{2}{|l|}{ Alteroatives } & \multicolumn{2}{|c|}{ Consequences to Alternatives } \\
\hline 5 & & 6 & \\
\hline $\begin{array}{l}\text { Dexision Reached } \\
7\end{array}$ & & $\begin{array}{l}\text { Basis for Decision } \\
8\end{array}$ & \\
\hline $\begin{array}{l}\text { Dace Requested } \\
9\end{array}$ & $\begin{array}{l}\text { Sent To } \\
10\end{array}$ & & $\begin{array}{l}\text { Date Requested By } \\
\text { S/6/96 }\end{array}$ \\
\hline
\end{tabular}
foubd in Hanford soils (See attachment 1) provided by Environmenual Engineering.

(3) The density of the excavated soils is $1.6 \mathrm{~g} / \mathrm{cm}^{3}$.

4

Response 11 Responses 20 ibe sutement problems are: 1) Agree. 2) The 200-BP-1 crib doesn't belong to TWRS, use the 216-z- $20 \mathrm{crib}$. Use a volume of 2400 cuble mesers and an over-burden of 60,000 cuble meters. 3) Was not able to find different cata, use allachmen 1 as the bounding case. 4) Use a deusity of 1.4 grams per cubic centimeter. 12

\section{Response 12}

13

\begin{tabular}{l|l}
\hline Attrehoronts (List) & Refierences (List) 15
\end{tabular} 
$M-C L C-G-00234, R_{P 1}-$
Sheet 34 of 34

\begin{tabular}{|c|c|}
\hline $\begin{array}{l}\text { Responder } 11 \text { Name and Siganture } \\
16 \text { Lankford Ruffin } \mathcal{P} \text { 5.9.96 }\end{array}$ & $\begin{array}{l}\text { Responder } 22 \text { Nanse and Siganture } \\
17\end{array}$ \\
\hline Filed: & Routed: \\
\hline $\begin{array}{l}\text { Purber Action Requited (i.c., RML, Senior Managen } \\
18\end{array}$ & tion. t(c.) \\
\hline
\end{tabular}

\section{Atuchnent 1}

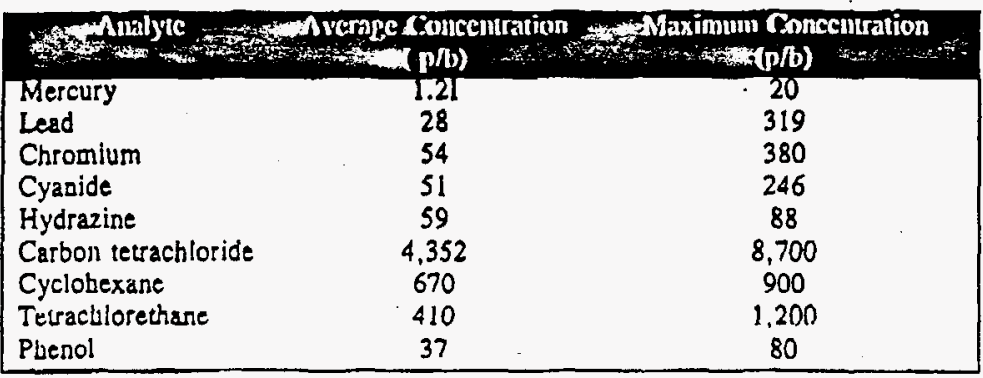




\section{DISTRIBUTION SHEET}

\begin{tabular}{|c|c|c|c|c|c|}
\hline \multirow{2}{*}{$\begin{array}{l}\text { To } \\
\text { Distribution }\end{array}$} & \multirow{2}{*}{\multicolumn{3}{|c|}{$\begin{array}{l}\text { From } \\
\text { G. W. Ryan }\end{array}$}} & \multicolumn{2}{|l|}{ Page 1 of 1} \\
\hline & & & & \multicolumn{2}{|c|}{ Date $7 / 29 / 96$} \\
\hline \multirow{2}{*}{\multicolumn{4}{|c|}{$\begin{array}{l}\text { Project Title/Work Order } \\
\text { Excavations in Hanford Ponds, Cribs, or Ditches. }\end{array}$}} & \multirow{2}{*}{\multicolumn{2}{|c|}{$\begin{array}{ll}\text { EDT No. } & \text { N/A } \\
\text { ECN No. } & 602624\end{array}$}} \\
\hline & & & & & \\
\hline Name & MSIN & $\begin{array}{l}\text { Text } \\
\text { With All } \\
\text { Attach. }\end{array}$ & Text Only & $\begin{array}{l}\text { Attach./ } \\
\text { Appendix } \\
\text { Only }\end{array}$ & $\begin{array}{l}\text { EDT/ECN } \\
\text { Only }\end{array}$ \\
\hline $\begin{array}{l}\text { C. Carro } \\
\text { D. S. Leach } \\
\text { TWRS S \& L Project Files (2) } \\
\text { G. W. Ryan } \\
\text { Central Files (Original + 1) }\end{array}$ & $\begin{array}{l}\text { A2-34 } \\
\text { A3-34 } \\
\text { A2-26 } \\
\text { A3-37 } \\
\text { A3-88 }\end{array}$ & $\begin{array}{l}x \\
x \\
x \\
x \\
x\end{array}$ & & & \\
\hline
\end{tabular}

